\title{
Mapping temporal and spatial variation of sulphur and nitrogen deposition to a complex ecosystem in Campeche, Mexico
}

\author{
J. Cerón ${ }^{1}$, R. Cerón ${ }^{1}$, C. Aguilar ${ }^{1}$, C. Montalvo ${ }^{1}$, A. García ${ }^{1}$, \\ M. Muriel ${ }^{2}$, E. Ramírez ${ }^{3}$, A. Córdova ${ }^{1} \&$ C. Carballo ${ }^{1}$ \\ ${ }^{1}$ Chemistry Faculty, Autonomous University of Carmen, Mexico \\ ${ }^{2}$ Mexican Institute of Petroleum, Mexico \\ ${ }^{3}$ Chemistry Faculty, Autonomous University of Nuevo Leon, Mexico
}

\begin{abstract}
Throughfall deposition was measured in a complex ecosystem at the southeast of Mexico. Samples were collected in an annual basis at Xicalango-Atasta region in Campeche State. Ionic exchange resin collectors were used in 13 points in a multiple transects design. Ions retained were extracted and analyzed by colorimetry and turbidimetry. Mean throughfall deposition fluxes for $\mathrm{N}$ and $\mathrm{S}$ were 0.97 and $9.47 \mathrm{Kg} \mathrm{ha}^{-1} \mathrm{yr}^{-1}$. N deposition flux did not exceed the critical load proposed and was considerably lower than those values reported for other authors; however, throughfall deposition flux for $\mathrm{S}$ was 2 times higher than those proposed for sensitive areas in Europe, suggesting that $\mathrm{S}$ deposition could be a threat for the mangrove ecosystems and fisheries in the region. Long-range transport of regional pollutants was evident during all seasons. Throughfall deposition maps were obtained by geo-statistic techniques and it was possible to identify two deposition hotspots in the region: oil and gas production facilities and vehicular emissions from federal highway.

Keywords: spatial distribution, throughfall deposition, $N$ and $S$ deposition, Campeche, Mexico.
\end{abstract}

\section{Introduction}

Total atmospheric measurements are required to estimate input-output budgets, assessment of biological, ecological and watershed responses to air pollutants, and 
to relate emission patterns with actual deposition to ecosystems. These observations about chemical composition and physical characteristics of the atmosphere at global, regional and local scales are required to propose new environmental policies focused to protect not only public health but also ecosystems. An effective design of air quality policies requires establishing long term global, regional and local monitoring of the atmosphere to understand and quantify current conditions, compare actual with past conditions and reference values, and diagnose the real effect of actual emission patterns on resulting $\mathrm{N}$ and $\mathrm{S}$ deposition to ecosystems. Critical loads have been defined as quantities of air pollutants that one ecosystem can be exposed without suffer harmful effects. However, the sensitivity varies among ecosystems due to some factors such as differences in local soil composition, chemical weathering of basic cations, sulphur deposition rates, type of ecosystem, and so on, therefore resulting in large variations among diverse receptors. Differences between air pollutant input and critical load values on a local scale can be identified as exceedances [1]. Maps of deposition loads are used to calculate exceedances of thresholds as critical loads, aimed to protect different receptors. Maps design is based upon network data measurements, model estimates and high resolution land use maps. Then, air pollution levels and critical loads must be mapped together in order to implement regionalized emission control strategies. The range of exceedances can be related with sensitivity categories, so, it is possible to diagnose the ecosystem vulnerability to $\mathrm{S}$ and $\mathrm{N}$ inputs. However, the main problem during this process is to find enough and reliable deposition data. Fenn and Bytnerowicz [2] proposed throughfall collectors to quantify atmospheric deposition in forests by ionic exchange resins (IER). Some authors have carried out comparisons between available collection techniques for measuring deposition [3]. Lovland et al. [4] concluded that throughfall collectors can be used to quantify the total deposition of sulphur and reported a strong relationship between throughfall deposition of $\mathrm{N}$ and the presence of nitrate in soils. From a combination of mapping, by geostatistic tools, and measurements of $\mathrm{N}$ and $\mathrm{S}$ throughfall deposition fluxes is possible to study spatial and temporal variability of deposition. In this study, throughfall deposition was collected by using IER collectors in order to map spatial and temporal variability of $\mathrm{N}$ and $\mathrm{S}$ deposition in a complex ecosystem in Campeche, Mexico.

\section{Study area}

Campeche coast has important natural protected areas and supports an extensive industrial activity that includes oil and gas exploring and production in continental and offshore facilities. It results in a complex frame where valuable natural resources and petroleum industry co-exist. Xicalango-Atasta is an area of $190 \mathrm{~km}^{2}$, a length of $50 \mathrm{~km}$, and an average depth of $2.7 \mathrm{~m}$ (Figure 1), located in the western portion of Terminos Lagoon, comprising three communities (Xicalango, Puerto Rico and Atasta) and two important ecological regions (Terminos Lagoon and the Pom-Atasta Lagoon System) with the presence of extensive mangrove forest. 


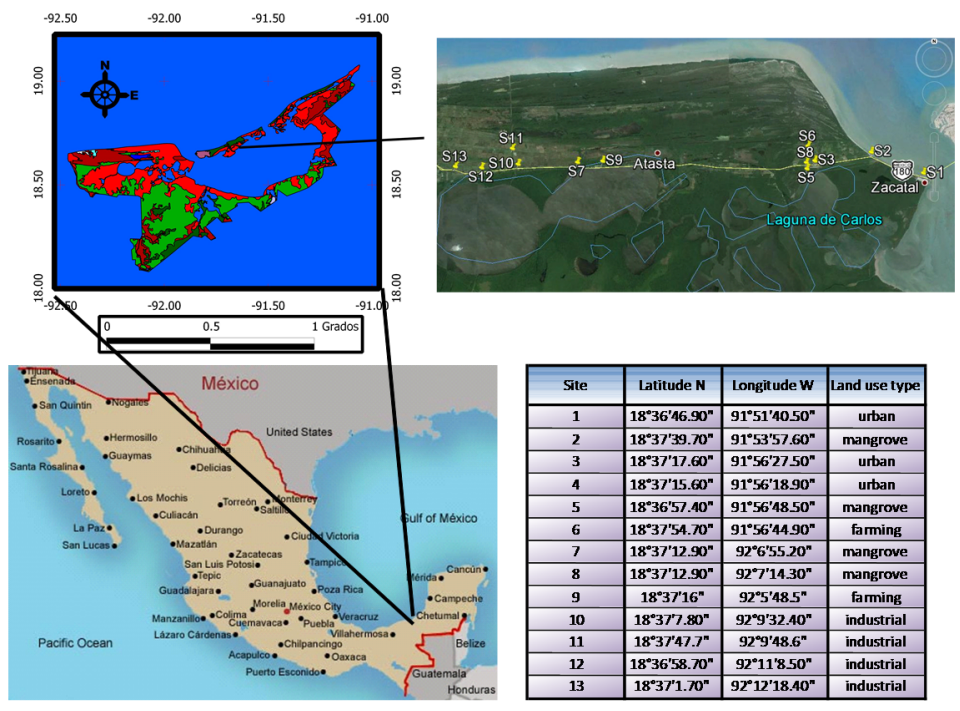

Figure 1: Sampling sites location.

\section{Methodology}

\subsection{Sampling method}

IER collectors were used in order to obtain throughfall deposition samples according to Fenn and Poth [5]. The IER collector consists of a funnel connected to a column containing ion exchange resin. Deposition falls on the funnel surface, washing down into the column. The main advantage of this passive sampler is that can be used for long exposure periods (e.g. months) and the equipment has a low cost. It lets to increase the number of the sampling points in a given area; therefore, it is feasible to deploy a large number of them to characterize spatial deposition patterns with a high resolution [6]. A multiple transects design with 13 sampling points was used and a mixed resin column design (containing both, anion and cation exchange resin beds) was chosen. Passive sampling devices were exposed from 5 July 2014 to 6 May 2015, with five sampling sub-periods of two months. At the end of each sub-period, resin tubes were changed by fresh resin tubes. Sampling sites location is presented in Figure 1.

\subsection{Analysis method}

Resin columns underwent two sequential extractions with $100 \mathrm{ml}$ of $2 \mathrm{~N} \mathrm{KCl}$. The extracts were analyzed for $\mathrm{NO}_{3}{ }^{-}, \mathrm{SO}_{4}{ }^{2-}$ and $\mathrm{NH}_{4}{ }^{+}$[7-9]. Three IER columns used as blanks were extracted and analyzed; the average blank IER column values were calculated and subtracted from the total ions recovered from each loaded resin column. Solute-mass was divided by funnel surface-area and total exposure period to obtain deposition rates of $\mathrm{N}$ (as $\mathrm{NO}_{3}{ }^{-}+\mathrm{NH}_{4}{ }^{+}$) and $\mathrm{S}$ (as $\mathrm{SO}_{4}{ }^{2-}$ ) in $\mathrm{Kg} \mathrm{ha}^{-1} \mathrm{yr}^{-1}$. 


\subsection{Statistical analysis}

The Friedman test was used to determine whether the determined atmospheric deposition fluxes were differing among the sampling sites, according to the landuse category or among the sampling season. The Friedman test [10] is a nonparametric test that can be used with block designs in which the underlying assumptions are not as restrictive as an ANOVA procedure. (Infostat 2014 version, http://www.infostat.com.ar/).

\subsection{Mapping method}

Geo-statistic is used to predict new values of sample variables over the whole area of interest, which is referred to a spatial prediction or spatial interpolation. Geographical part can be modelled by using either a continuous, discrete or mixed model of spatial variation [11]. Temporal variability makes geo-statistic mapping be expensive and complex. Considering that seasonal periodicity is regular for studied environmental parameters, spatial variability was analyzed for dry, rainy and north seasons. Coordinates of the measurement sites and attributed concentration were input to derive point maps showing the scatter and measured concentration of the different species. In a second step, the concentration of closely neighbouring sampling points within each grid cell were averaged to one value and attributed to one point. These points were input for kriging interpolation procedure [1]. Deposition field contours were smoothed using the kriging method [12]. The kriging weights were computed from a variogram, which measured the degree of correlation among samples values in the area as a function of distance and direction of samples.

\section{Results and discussion}

\subsection{NH4+ throughfall deposition fluxes (TDF) and mapping}

TDF for $\mathrm{NH}_{4}^{+}$ranged from 0.01 to $2.66 \mathrm{Kg} \mathrm{ha}^{-1} \mathrm{yr}^{-1}$. An evident seasonal pattern was found with $\mathrm{NH}_{4}{ }^{+}$fluxes higher during the dry season (Figure 2) (at the $95 \%$ significance level, according to the Friedman test results), suggesting that local sources could contributed to $\mathrm{NH}_{4}{ }^{+}$deposition. The possible sources in this area include: a sour gas recompression plant located in this surroundings, the 180 federal highway which crosses the wide peninsula and small temporary crops. Two sampling sites (SS) were identified with highest levels of $\mathrm{NH}_{4}^{+}$throughfall deposition (Figure 2(b)). SS4 (1.9 Kg ha-1 $\mathrm{yr}^{-1}$ ) is located in Puerto Rico community and corresponds to a big parking lot for heavy vehicles that transport fuels and food from the central part of Mexico to Yucatan Peninsula. Bishop et al. [13] have reported $\mathrm{NH}_{3}$ emissions from vehicular sources that finally are deposited as ammonium. In this case, this contribution is not seasonal, because of this source is contributing all time to background levels in this region. There are several small crops in this zone that could use fertilizers contributing to $\mathrm{NH}_{4}{ }^{+}$deposition during the dry season. However, the land use with the higher $\mathrm{NH}_{4}{ }^{+}$deposition $(2.66 \mathrm{Kg}$ 


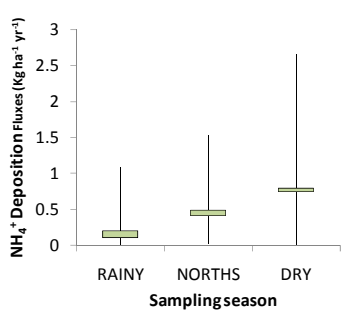

(a) by season

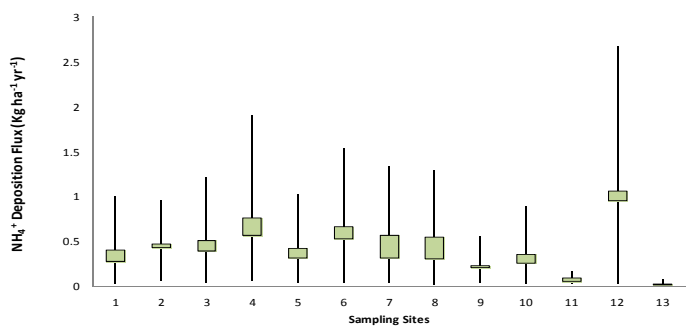

(b) by sampling site

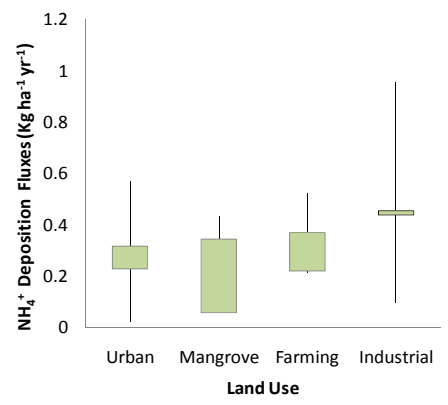

(c) by land use

Figure 2: $\quad$ TDF for $\mathrm{NH}_{4}^{+}$at Xicalango-Atasta.

$\mathrm{ha}^{-1} \mathrm{yr}^{-1}$ ) was an industrial zone, where SS12 is located (Figures 2(b) and 2(c)). In this point two sources are located: a sour gas recompression plant and a fuel station, which could contribute in a great proportion to $\mathrm{NH}_{4}^{+}$levels. Significant differences were found for $\mathrm{NH}_{4}{ }^{+}$atmospheric deposition fluxes among sampling sites and for different land-use categories, according to the Friedman test. In Figure 3, two hotspots for $\mathrm{NH}_{4}{ }^{+}$deposition can be observed along the year, corresponding to SS4 and SS12 (Puerto Rico community; and fuel station and sour gas recompression plant).

\subsection{NO3- throughfall deposition fluxes (TDF) and mapping}

TDF for $\mathrm{NO}_{3}{ }^{-}$ranged from 0.03 to $2.06 \mathrm{Kg} \mathrm{ha}^{-1} \mathrm{yr}^{-1}$. An evident seasonal pattern was found (Figure 4(a)), with the highest values during the rainy season $(0.75 \mathrm{Kg}$ $\left.\mathrm{ha}^{-1} \mathrm{yr}^{-1}\right)$. Significant differences at 95\% significance level were found for $\mathrm{NO}_{3}{ }^{-}$ deposition fluxes among the different sampling seasons according to the Friedman test. A spatial pattern was also observed (Figure 4(b)), with the highest values in SS8 (1.57 Kg ha-1 $\mathrm{yr}^{-1}$ : corresponding to Atasta town, which is located along the 180 federal highway, which has many speed bumps, therefore, it is probably that the most important contributing source to these $\mathrm{NO}_{3}{ }^{-}$high levels are vehicles passing by this road and subjected to an acceleration-deceleration pattern) and SS12 (2.06 Kg ha-1 $\mathrm{yr}^{-1}$ : corresponding to an industrial zone where a fuel station and a sour gas recompression plant are located) (Figure 4(c)). Significant 


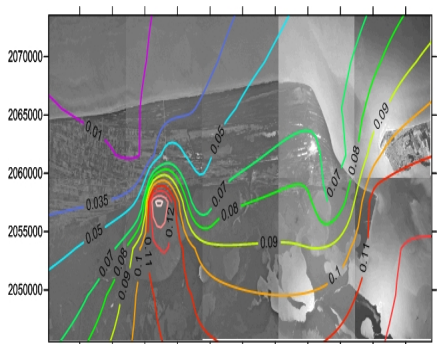

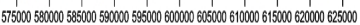

(a) Rainy season

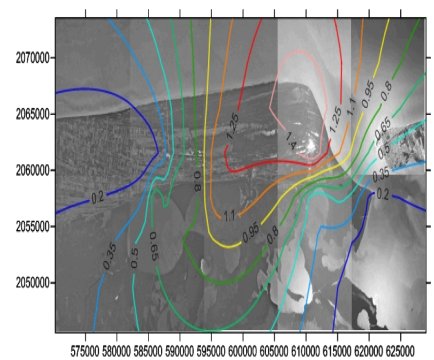

(b) Norths season

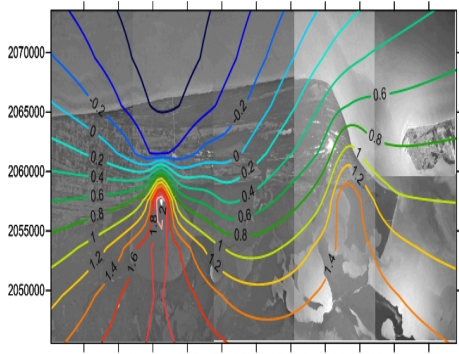

57500058000058550059900005950006000006050006610000615000620000625000

(c) Dry season

Figure 3: TDF Maps for $\mathrm{NH}_{4}{ }^{+}$at Xicalango-Atasta.

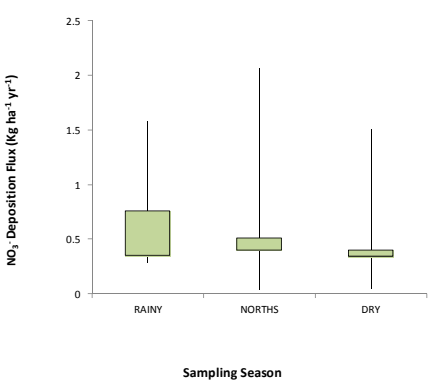

(a) by season

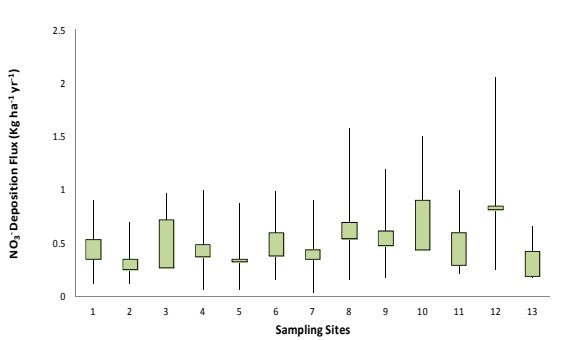

(b) by sampling site

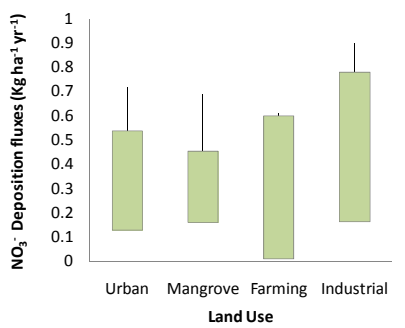

(c) by land use

Figure 4: $\quad$ TDF for $\mathrm{NO}_{3}{ }^{-}$at Xicalango-Atasta. 
differences were found for $\mathrm{NO}_{3}{ }^{-}$deposition fluxes among sampling sites and for different land-use categories according to the Friedman test. Maps for $\mathrm{NO}_{3}{ }^{-}$ deposition fluxes are shown in Figure 5 where two hot spots were identified: SS4 and SS12, being most important SS2, which is a highly industrial zone, where a fuel station is also placed.

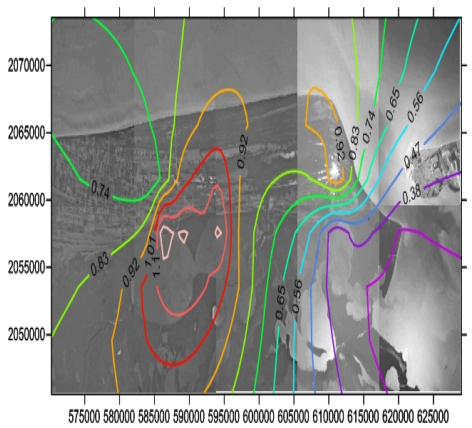

(a) Rainy season

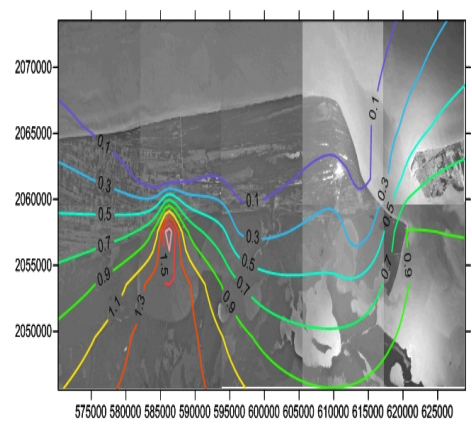

(b) Norths season

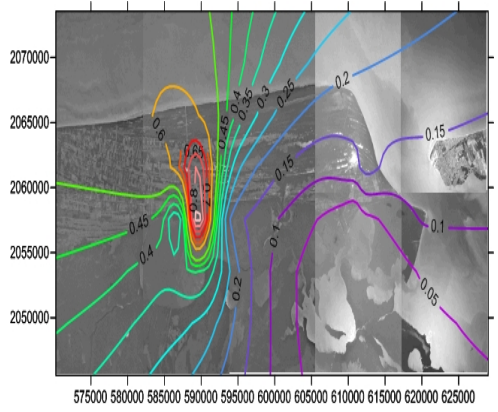

(c) Dry season

Figure 5: TDF Maps for $\mathrm{NO}_{3}{ }^{-}$at Xicalango-Atasta.

\section{3 $\mathrm{SO}_{4}{ }^{2-}$ throughfall deposition fluxes (TDF) and mapping}

$\mathrm{SO}_{4}{ }^{2-}$ deposition was almost six times higher comparing than those found for ammonium and nitrate. TDF for $\mathrm{SO}_{4}{ }^{2-}$ ranged between 3.19 to $14.06 \mathrm{Kg} \mathrm{ha}^{-1} \mathrm{yr}^{-1}$.

A seasonal pattern was identified (Figure 6(a)), with slightly higher levels during norths season, showing significant differences among three sampling periods according to the Friedman test results. On the other hand, $\mathrm{SO}_{4}{ }^{2-}$ deposition levels did not varied significantly neither among sampling sites (Figure 6(b)) nor among land-use categories (Figure 6(c)). According to the Friedman test, only five sites showed significant differences and there were not significant differences among the different land-use categories for $\mathrm{SO}_{4}{ }^{2-} \mathrm{TDF}$. Hence the fact that regional sources contributed to deposition process of this ion, enhancing the background levels in this region, it strongly supported. Moreover, this is agreement with the regional character of $\mathrm{SO}_{4}{ }^{2-}$ and its precursor $\left(\mathrm{SO}_{2}\right.$ has a residence time $\sim 13$ days), 


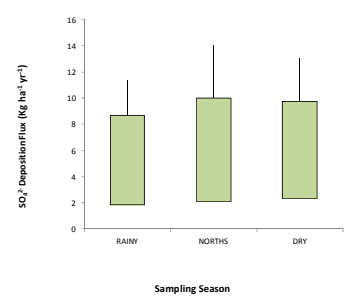

(a) by season

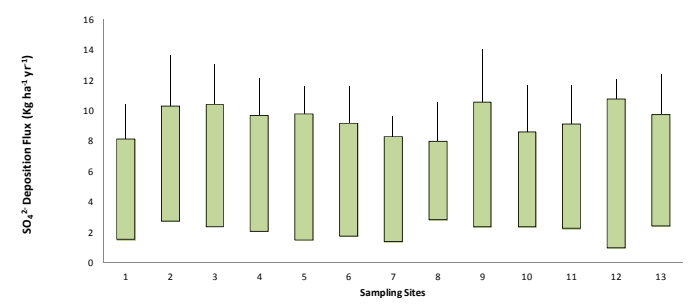

(b) by sampling site

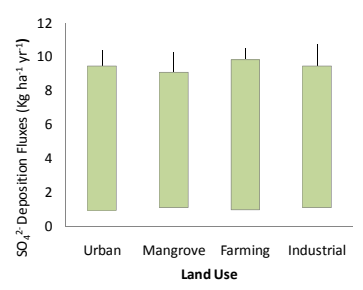

(c) by land use

Figure 6: $\mathrm{TDF}$ for $\mathrm{SO}_{4}{ }^{2-}$ at Xicalango-Atasta.

and demonstrates that during the cold fronts season (norths season), this region is downwind from offshore platform emissions. During all year this region is subjected to meteorological phenomena that promote the long-range transport of air pollutants from several sources. During cold fronts, the main source is offshore complex for gas and oil production in Campeche Gulf, whereas during tradewinds, the main sources are located in Yucatan Peninsula. Figure 7 shows two hotspots, the first one, positioned at the east edge of the wide peninsula that corresponds to an area highly exposed to long-range transport. The second main source is located in the surroundings of the sour gas recompression station, where flares, used to avoid over-pressure in the recompression equipment, are burning periodically sour gas, contributing to the background levels of $\mathrm{SO}_{4}{ }^{2-}$ in this region. Given that there are not available references values for Mexico, obtained results, in this research, were compared with those found by some authors in other regions of the world. S deposition was comparable to that obtained by Fenn et al. [15] in forest sites in the surroundings of Mexico City, but lower than those reported by Ponette et al. [14] and Boxman et al. [16] in Central Veracruz, Mexico and in The Netherlands, respectively.

$\mathrm{N}$ deposition in this study was considerably lower than those values reported for Mexico City Air Basin [15], Southwestern Colombia [17], Northeast of United States [18], Southern California [2] and The Netherlands [16].Throughfall fluxes for $\mathrm{N}$ and $\mathrm{S}$ in this study were compared with critical load values proposed for European countries to provide an indicator of the possible vulnerability of this ecosystem.

A critical load value of $5 \mathrm{Kg} \mathrm{N} \mathrm{ha-1} \mathrm{yr}^{-1}$ has been proposed for alpine ecosystems [19] whereas a value of $3 \mathrm{Kg} \mathrm{S} \mathrm{ha}^{-1} \mathrm{yr}^{-1}$ has been proposed as a 


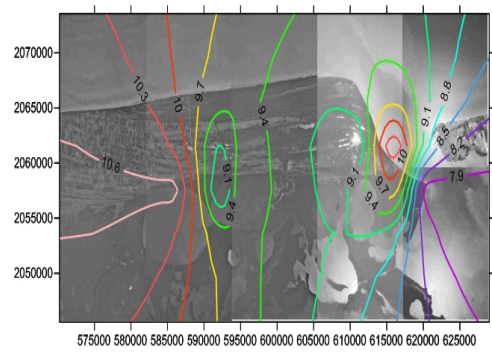

(a) Rainy season

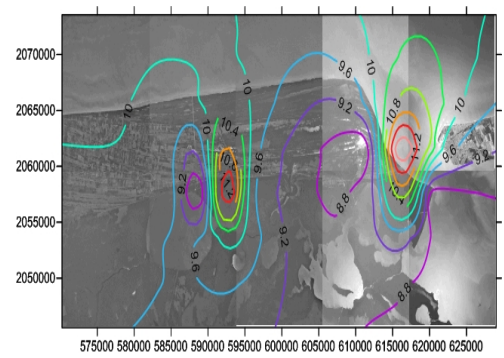

(b) Norths season

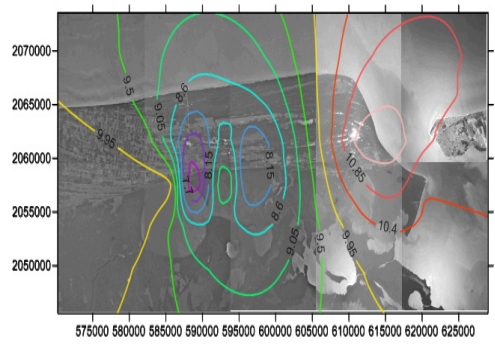

(c) Dry season

Figure 7: TDF Maps for $\mathrm{SO}_{4}{ }^{2-}$ at Xicalango-Atasta.

reference value for very sensitive areas. $\mathrm{N}$ deposition did not exceed the critical load value proposed for sensitive ecosystems in Europe. $\mathrm{S}$ deposition levels were comparable to those found in disturbed ecosystems in other countries, and they exceeded critical load values for natural forests and very sensitive ecosystems in Europe, suggesting an evident influence of the oil and gas industry. Environmental impacts produced by the cycle of oil exploration and production and their effects in the air ambient in Mexico are not fully documented. However, an estimation of annual emissions in industrial sources in the studied region [20] reports 150,893.7 $\mathrm{Mg} \mathrm{yr}^{-1}$ for $\mathrm{SO}_{\mathrm{x}}$, whereas Schifter et al. [21] and Villaseñor et al. [22] performed an air quality emissions inventory for offshore operations in the Bay of Campeche, reporting 185, 907 and 181,002 tons $\mathrm{yr}^{-1}$ for $\mathrm{SO}_{\mathrm{x}}$, respectively.

\section{Conclusions}

There was a clear seasonal pattern for ammonium, nitrate and sulfate. The local character of ammonium and nitrate was evident, and spatial variability allowed to identify vehicular and industrial emissions, and agriculture, as the main sources. In the case of sulfate, it was demonstrated that meteorological conditions prevailing all year in this region promotes the long-range transport, suggesting that sulfate had a regional character with mixed sources. From the mapping of throughfall $\mathrm{N}$ and $\mathrm{S}$ deposition, it was possible to identify some hotspots in this region, therefore, data obtained here, can be used as a baseline for local public policies in the future focused to protect both, public health and ecosystems. 
Regarding to $\mathrm{N}$ deposition, it is not expected to cause serious perturbations in nutrient cycling. In spite of region has a high soil buffering capacity (with soils from neutral to alkaline due to their carbonated nature), it is characterized by nutrient-poor and sandy soils, which could be vulnerable to euthrophication. Since $\mathrm{S}$ deposition values obtained in this research exceeded almost two times the critical load values reported for European countries, this could be a threat for the protected areas, crops and natural sites in the study region. Therefore, a range of critical loads for $\mathrm{N}$ and $\mathrm{S}$ is required for this ecosystem in Mexico. From this information, and current deposition fluxes, will be possible to estimate their exceedances, these exceedances can be related to sensitivity classes to indicate if ecosystems in this region could be vulnerable or not, to the current $\mathrm{S}$ and $\mathrm{N}$ deposition levels.

\section{References}

[1] UBA. Manual on methodologies and criteria for mapping critical levels/loads and geographical areas where they are exceeded. UBA Texte 71/96. http://www.umweltbundesamt.de/mapping/, 1996.

[2] Fenn, M.E. \& Bytnerowicz, A. Summer throughfall and winter deposition in the San Bernardino Mountains in Southern California. Atmos. Env., 31, pp. 673-683, 1997.

[3] Warfvinge, P. Integrating modeling (Chapter 1). Acid atmospheric deposition and its effects on terrestrial ecosystems in the Netherland, the third and Final Phase, ed. G.J. Heij \& J.W. Erisman, 1997.

[4] Lovland, G., Andersen, B., Joffre, S., Pedersen, U., Hormand, M. \& Reissell, A. Mapping deposition of sulphur, nitrogen, and base cations in the Nordic Countries. Swedish Environmental Research Institute. Report B 1055. 1992-06-25, 1992.

[5] Fenn, M.E. \& Poth, M.A. Temporal and spatial trends in streamwater nitrate concentrations in the San Bernardino Mountains in Southern California. $J$. Environ. Qual., 28, pp. 822-836, 1999.

[6] Clow, D., Roop, H., Nanus,L., Fenn, M. \& Sexstone, G. Spatial patterns of atmospheric deposition of nitrogen and sulfur using ion-exchange resin collectors in Rocky Mountain National Park, USA. Atmos. Env., 101, pp. 149-157, 2015.

[7] NMX-AA-079-SCFI-2001. Water Analysis. Determination of nitrates in natural water, potable water, and waste water (Determinación de nitratos en aguas naturales, potables, residuales y residuales tratadas), 2001.

[8] Fresenius, W., K.E. Quentin., Schneider, W. Water Analysis. Springer Verlag: Berlín. 804 pp., 1988.

[9] NMX-AA-074-SCFI-1981. Water Analysis. Determination of sulfate ion in natural water and waste water (Determinación del ión sulfato en aguas naturales, residuales y residuales tratadas), 1981.

[10] Conover, W.J. Practical Non-Parametric Statistics. Wiley: New York. 299 pp., 1980. 
[11] Hengi, T. A practical guide to geostatistical mapping of environmental variables. JRC Scientific and technical reports. European Commission. Joint Research Centre. Ispra, Italy, 2007.

[12] Matheron, G. Principles of geostatistics. Economic geology, 58, pp. 12461266, 1963.

[13] Bishop, G.A., Peddle, A.M. \& Stedman, D.H. On-road emission measurements of reactive nitrogen compounds from three California cities. Environ, Sci. Technol., 44, pp. 3616-3620, 2010.

[14] Ponette, A.G., Weathers. K.C. \& Curran, L.M. Tropical land-cover alters biogeochemical inputs to ecosystems in a Mexican montane landscape. Ecological Applications, 20, pp. 1820-1837, 2010.

[15] Fenn, M.E., de Bauer, L.I., Quevedo-Nolasco, A. \& Rodríguez-Frausto, C. Nitrogen and Sulfur deposition and forest nutrient status in the Valley of Mexico. Water, air \& soil pollution, 113, pp. 155-174, 1999.

[16] Boxman, A.W., Peters, R.C. \& Roelofs, J.G. Long-term changes in atmospheric $\mathrm{N}$ and $\mathrm{S}$ throughfall deposition and effects on soil solution chemistry in a Scots pine forests in The Netherlands. Environmental Pollution, 156, pp. 1252-1259, 2008.

[17] Burbano-Garcés, M.L., Figueroa-Casas, A. \& Peña, M. Bulk precipitation, throughfall, and stemflow deposition of N-NH4, N-NH3, and N-NO3 in an Andean forest. Journal of Tropical Forest Science, 24, pp. 446-457, 2014.

[18] Kopacek, J., Hejzlar, J. \& Mosello, R. estimation of organic acid anion concentrations and evaluation of charge balance in atmospherically acidified colored waters. Water Research, 34, pp. 3598-3606, 2000.

[19] Dieter, H. \& Gouger, T. Critical load, dynamic modeling and impact assessment in Europe. C.E.E. Status. Report. 2000.

[20] INE-SEMARNAT. National Emissions Inventory 1999. First Edition. México, D.F. 2006.

[21] Schifter, I., González, C., Miranda, A. \& López, E. Air emissions assessment from offshore oil activities in Sonda de Campeche, Mexico. Environmental Monitoring and Assessment, 109, pp. 135-145, 2005.

[22] Villaseñor, R., Magdaleno, M., Quintanar, A., Gallardo, J., López, M; Jurado, R., Miranda, A., Aguilar, M., Melgarejo, L., Palmerín, E., Vallejo, C. \& Barchet, W. An air quality emission inventory of offshore operations for the exploration and production of petroleum by the Mexican oil industry. Atmospheric Environment, 37, pp. 3713-3729, 2003. 